\title{
Factors Affecting Root of Stem Cuttings of Salt Desert Shrubs
}

\author{
STEVEN G. RICHARDSON, JERRY R. BARKER, KENT A.CROFTS AND GORDON A. VAN EPPS
}

\section{Abstract}

Several variables were identified that affect rooting of stem cuttings of fourwing saltbush (Atriplex canescens), cuneate saltbush $(A$. cuneata), shadscale $(A$. confertifolia), spiny hopsage (Grayia spinosa) and greasewood (Sarcobatus vermiculatus). Differences in rooting were found among different individuals within the same population. Rooting varied with season of collection and with concentration of hormone application. There was an interaction between the effects of season of collection and concentration of applied hormone. Longer fourwing saltbush cuttings rooted better than shorter ones, and woody basal portions of new leaders rooted better than herbaceous tips. Sex of dioecious saltbush species was generally not an important factor in rooting success. Cuttings from greasewood plants grown in a greenhouse rooted better than field-collected cuttings.

Vegetative propagation of desert shrubs is a means of producing a number of genetically identical individuals in species whose sexually produced offspring are normally highly variable. Reduced variability of plant materials can increase experimental precision, and a large number of genetically identical individuals is necessary for varietal testing. Reproduction of desirable parent characteristics such as high seed yield would be valuable in the establishment of seed production nurseries. Vegetative propagation is also a method of producing transplants of species whose seeds do not germinate readily.

The propagation of stem cuttings of several saltbush (Atriplex) species and a few species from other salt desert shrub genera have been studied by Nord and Goodin (1970), Wieland et al. (1971), Ellern (1972), and Wiesner and Johnson (1977). Although these studies have provided much useful information, they have also raised further questions that need to be addressed. For example, it was not clear why hormone treatments sometimes enhanced rooting and sometimes did not. Although Nord and Goodin (1970) and Ellern (1972) observed a general trend for better rooting of saltbush (Atriplex) species in spring than fall, no data were available for summer and winter. Nord and Goodin (1970) noted better rooting of green stem tips than ripewood cuttings, but Ellern (1972) failed to find any difference in rooting of soft, green cuttings and young woody stems cuttings.

Certain other factors not addressed by the above cited research might also be important to the successful rooting of salt desert shrub stem cuttings. Freeman et al. (1976) found that for several dioecious species, including shadscale (Atriplex confertifolia), male plants were more abundant on harsher sites

Al time of study authors were. respectively, senior research technician, rescarch assistant. research technician, and associate professor with the Range Science Department and Institute for Land Rehabilitation, Utah State University, Logan 84322. Van Epps is stationed at Snow Field Station, Ephraim. Utah. Current address of Crofts is Energy Fuels Corp.. Steamboat Springs. Colo.

Research was sponsored by the Utah A rricultural Experiment Station with a grant from the Cooperative State Research Service, U.S. Dep. Agr., and a research contract with the II hite River Shate Project (Sunoco Energy Development Co., Sohio Natural Resources (i). and Phillips Petroleum Co.).

Manuscript received Junc 15.1978. (more saline or xeric) and females were more abundant on the less harsh sites, suggesting that the sexes may differ in their physiological ability to survive stress. It is possible that physiological differences between sexes might also include the ability to produce adventitious roots on stem cuttings. The size of cuttings and the environmental conditions under which the donor plants are grown may also affect rooting.

Research was conducted to shed further light on factors affecting adventitious root formation on salt desert shrub stem cuttings. The specific research objectives were to: (1) identify the optimum season to collect stem cuttings of fourwing saltbush (Atriplex canescens) and cuneate saltbush (A. cuneata); (2) determine whether or not sex of dioecious saltbush species is important to rooting of cuttings; (3) study the response of shadscale, fourwing saltbush, and spiny hopsage (Grayia spinosa) to various concentrations of exogenously applied indole-3-butyric acid (IBA); (4) determine whether there is an interaction of season of collection with concentration of applied hormone on rooting response of fourwing saltbush; (5) determine how size of stem cuttings and portion of stem used for cuttings affected rooting of fourwing saltbush; and (6) compare rooting of greasewood (Sarcobatus vermiculatus) cuttings collected from field-grown and greenhouse-grown plants.

\section{Methods}

\section{Collection Sites}

Stem cuttings of fourwing saltbush (Atriplex canescens), cuneate saltbush ( $A$. cuneata), shadscale $(A$. confertifolia), spiny hopsage (Grayia spinosa), and greasewood (Sarcobatus vermiculatus) were collected from the vicinity of Bonanza, Uintah County, Utah. Elevations of the Bonanza collection sites range from about $1,585 \mathrm{~m}$ $(5,200 \mathrm{ft})$ to $1,707 \mathrm{~m}(5,600 \mathrm{ft})$ and average annual precipitation ranges from $18 \mathrm{~cm}$ ( 7 inches) to $23 \mathrm{~cm}$ (9 inches). The salt desert shrub vegetation is grazed during the winter by sheep. For certain of the experiments, as explained below, stem cuttings of fourwing saltbush, cuneate saltbush, and shadscale were collected from Wildcat Mesa and Pete Steele Bench, two adjacent mesas in eastern Garfield County, Utah. Elevations of the Wildcat Mesa and Pete Steele Bench collection sites range from $1,707 \mathrm{~m}(5,600 \mathrm{ft})$, to $1,768 \mathrm{~m}(5,800 \mathrm{ft})$, with average annual precipitation in the $20-\mathrm{cm}(8$ inches) to $23-\mathrm{cm}(9$ inches) range. The vegetation is salt desert shrub and the primary use of the land has been for winter cattle grazing.

\section{General Propagation Techniques}

The youngest available woody stems (current year's growth in summer and previous season's growth in winter) were collected from the above field sites and placed in plastic bags. The plastic bags of cuttings were transported in styrofoam chests. Stem sections $8 \mathrm{~cm}$ long (except in the experiment comparing cutting length), with the lower 2 $\mathrm{cm}$ of leaves removed, were dipped first in water and tapped against the side of the container to remove excess water. The moistened cuttings were then dipped in talc powder containing indole-3-butyric acid (IBA) and excess powder was removed by tapping the cuttings against the container. IBA in talc powder was used because IBA has 
been shown to be probably the best hormone for general use due to its effectiveness in promoting root initiation of a large number of plant species and its general lack of toxicity over a wide concentration range (Hartman and Kester 1975). A concentration of $0.3 \%$ IBA was used, except in experiments testing effects of hormone concentration, because it had proved effective in preliminary experiments for promoting root initiation of several salt desert shrub species.

After hormone treatment, the cuttings were inserted one each into moistened peat pellets in plastic trays with inside dimensions of 50.8 $\mathrm{cm} \times 25.4 \mathrm{~cm} \times 6.4 \mathrm{~cm}$. The trays of peat pellets with cuttings were kept in a translucent polyethylene enclosed chamber in a glasshouse. One side of the chamber was left open during the day to prevent excessive heat build-up. No supplemental lighting was provided.

The cuttings were sprinkled with water daily. Holes in the bottom of the trays allowed adequate drainage. A temperature of $21^{\circ} \mathrm{C}$ was maintained in the growth medium with thermostatically controlled electric heating pads. Air temperatures in the chamber ranged from $15^{\circ} \mathrm{C}$ to $29^{\circ} \mathrm{C}$ in winter and from $17^{\circ} \mathrm{C}$ to $35^{\circ} \mathrm{C}$ in summer. Cuttings were examined for root initiation after 30 days in the propagation chamber.

\section{Season of Collection}

Cuneate saltbush and fourwing saltbush were collected at various limes from Bondiza, Utah, during the period of March 1976 through August, 1977. At each collection date 50 cuttings from each of 5 plants per species were treated as above with $0.3 \%$ IBA in talc. Percent rooting was determined after cuttings had been in the propagation chamber 30 days. The experimental design was completely randomized.

\section{Sex of Dioccious Atriplex}

Cuttings were collected from male and female fourwing saltbush, cuneate saltbush, and shadscale plants. Collection dates and locations are listed in Table 1. There were 5 plants per sex and 50 cuttings per plant except on the January, 1977, collection date for fourwing saltbush, when 20 male and 20 female plants were collected. After collection, cuttings were treated as stated above.

\section{Hormone Concentration and Interaction with Season of Collection}

Fifty cuttings per treatment per plant from 5 shadscale, 10 fourwing saltbush, and 4 spiny hopsage plants were collected from the vicinity of Bonanza, Utah, in March, 1977, and treated with various concentrations $(0,0.1,0.3,0.8,2.0 \%)$ of IBA in talc powder. In addition, fourwing saltbush cuttings collected the previous December and the following August were also treated with the same range of IBA concentrations. There were 50 cuttings from each of 5 plants per treatment used in December and August. General propagation techniques were as stated above.

\section{Effects of Length of Cutting and Stem Portion Used}

Three lengths $(6 \mathrm{~cm}, 9 \mathrm{~cm}$ and $12 \mathrm{~cm})$ of stem cuttings were taken from a greenhouse-grown fourwing saltbush clone (a group of genetically identical plants previously propagated from stem cuttings). Three replicates of seven cuttings per length were treated by the propagation techniques stated above.

The long leaders of the above clone were cut into top, middle, and bottom portions, all $8 \mathrm{~cm}$ long. Five replicates of seven cuttings for each portion were treated by the general techniques stated above.

\section{Greenhouse-Grown vs. Field-Collected Cuttings}

In several preliminary trials greasewood cuttings rooted poorly if at all. To determine whether rooting of cuttings could be improved by modifying the environment under which donor plants were grown, greasewood cuttings were collectcd from plants in the field and in the greenhouse on two dates. There were 105 field-collected cuttings and 84 greenhouse-collected cuttings on March 24, 1976, and there were 168 field-collected cuttings and 133 greenhouse-collected cuttings on January 7,1977 . The cuttings were treated with $2.0 \%$ IBA powder (most effective concentration in preliminary experiments) and were handled by the general propagation techniques outlined above. $\mathrm{Cu}$ tings were examined for root initiation after 40 days in the propagation chamber.

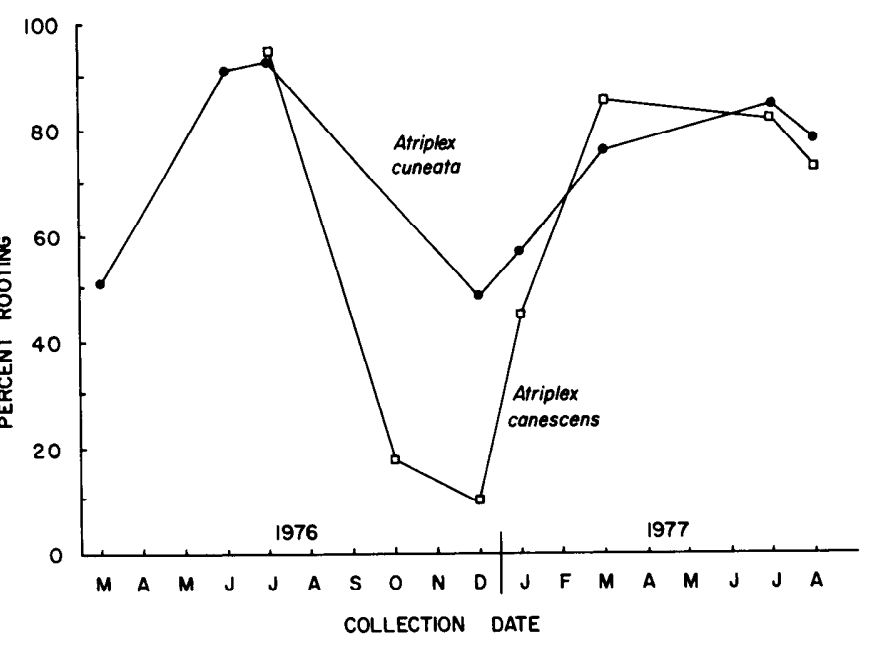

Fig. 1. Percent rooting of stem cuttings of fourwing saltbush and cuneate saltbush collected at different times of the year. Cuttings were treated with $0.3 \%$ $I B A$.

\section{Results and Discussion}

\section{Season of Collection}

Greatest rooting percentages of fourwing saltbush and cuneate saltbush occurred in spring and summer, while rooting percentages were lowest in the fall (Fig. 1). The seasonal difference in rooting is most striking with fourwing saltbush. The seasonal rooting response of these two saltbush species differs from that of big sagebrush (Artemisia tridentata). Big sagebrush produced peak rooting percentages in late winter, but adventitious root formation was much reduced after the onset of growth in the spring (Alvarez-Cordero 1977).

Although temperature of the rooting medium was maintained at $21{ }^{\circ} \mathrm{C}$ throughout the experiment, photoperiod and greenhouse air temperatures varied seasonally. Thus it was not possible to completely separate the effects of field and greenhouse environment. However, the conditions of the experiment are typical of those conditions that will be used by people attempting to propagate the above species, and the data provide a guide for the best times to collect cuttings from the field. The optimum time for collecting cuttings from these saltbush species may be expected to vary slightly depending on elevation and latitude.

In general, highest rooting percentages of fourwing and cuneate saltbushes can be expected in the period just following the cessation of rapid spring vegetative growth before fall dormancy occurs. The period from bud swelling through rapid vegetative growth is the next most favorable for rooting of stem cuttings, followed by the late winter time during which any chilling requirement to break dormancy have probably already been met. Poorest rooting is expected during the earlier stages of dormancy in late fall. A few trials with other saltbush species (Atriplex gardneri, A. confertifolia and A. corrugata) suggest that they follow seasonal patterns similar to fourwing and cuneate saltbushes in their rooting responses. Other plant genera (e.g. Artemisia) may differ from Atriplex in seasonal ability of stem cuttings to initiate adventitious roots, and the optimum season for collection and rooting of their cuttings must be determined separately.

\section{Sex of Dioecious Atriplex}

Four separate trials with fourwing saltbush and two trials with shadscale indicate that the ability to form adventitious roots on stem cuttings is not related to the sex of these two species (Table 1). The initial trial with cuneate saltbush, collected October 23, 
Table 1. Percent rooting of three saltbush (Atriplex) species as affected by sex of stem cuttings.

\begin{tabular}{|c|c|c|c|c|c|c|}
\hline \multirow{2}{*}{$\begin{array}{c}\text { Collection } \\
\text { date }\end{array}$} & \multirow[b]{2}{*}{ Species } & \multirow[b]{2}{*}{ Location } & \multicolumn{2}{|c|}{$\operatorname{Sex}^{1}$} & \multirow{2}{*}{$\begin{array}{c}\text { Over-all } \\
\text { mean }\end{array}$} & \multirow[b]{2}{*}{ Range } \\
\hline & & & Male & Female & & \\
\hline $10-22-76$ & A. canescens & Bonanza & 18.8 & 19.6 & 19.2 & $0-76$ \\
\hline $1-7-77$ & A. canescens & Bonanza & 28.3 & 29.1 & 28.7 & $0-90$ \\
\hline $3-18-77$ & A. canescens & Wildcat Mesa & 6.7 & 12.0 & 9.4 & $0-28$ \\
\hline $3-20-77$ & A. canescens & Bonanza & 36.0 & 31.2 & 33.6 & $0-76$ \\
\hline $10-23-76$ & A. confertifolia & Wildcat Mesa & 20.7 & 25.4 & 23.1 & $4-54$ \\
\hline $12-4-76$ & A. confertifolia & Wildcat Mesa & 58.9 & 60.2 & 59.6 & $30-72$ \\
\hline $10-23-76$ & A. cuneata & Pete Steele Bench & $54.6^{*}$ & $18.6^{*}$ & 36.6 & $4-72$ \\
\hline $11-23-76$ & A. cuneata & Bonanza & 12.4 & 7.2 & 9.8 & $0-26$ \\
\hline $3-18-77$ & A. cuneata & Wildcat Mesa & $40.3 *$ & $72.0^{*}$ & 56.2 & $14-84$ \\
\hline
\end{tabular}

Means of 5 plants per sex, 50 cuttings per plant treated with $0.3 \%$ IBA powder except for A. canescens on 1-7-77, when 20 plants per sex were collected.

* Difference between sexes significant at .05 level.

1976, from Pete Steele Bench, resulted in significantly greater rooting percentages for cuttings from male than from female plants (Table 1). However, cuttings of female plants had significantly greater rooting percentages than cuttings of male plants collected March 18, 1977, from Wildcat Mesa, only a few miles from Pete Steele Bench. A third trial with cuneate saltbush collected from Bonanza on November 22, 1976, indicated no difference in rooting between sexes.

In the course of performing the above experiments, it became evident that individual plants within a given population of a species may differ considerably in percent of cuttings initiating roots. This is demonstrated by the sometimes great range of percent rooting values (Table 1). For example, the mean rooting percentage for 40 fourwing saltbush plants collected January 7 , 1977, was 28.7 , but certain individual plants rooted as high as $90 \%$ and many had less than $20 \%$ of the cuttings initiate roots. Such data suggest that it is possible to select easily rooted individuals from a plant population and establish clones in a

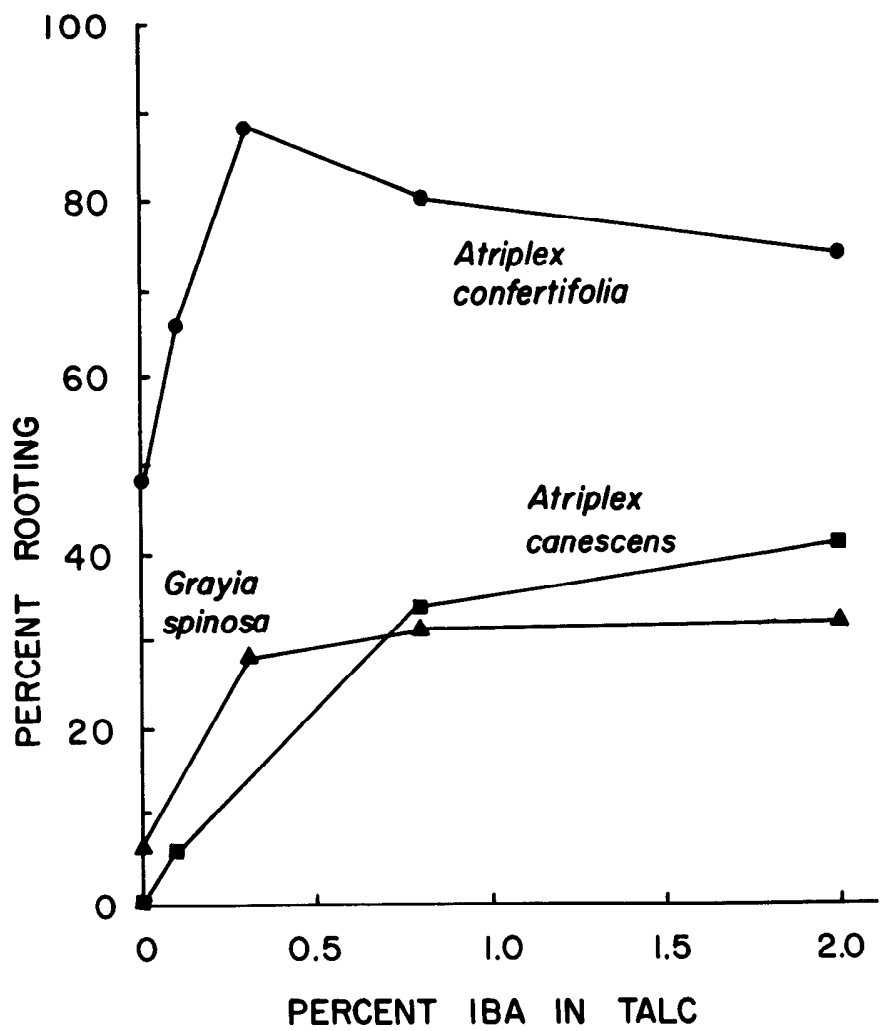

Fig. 2. Rooting response of shadscale, fourwing saltbush, and spiny hopsage cuttings treated with various concentrations of IBA. Cuttings were collected in March, 1977. nursery to supply stem material for large scale propagation efforts. This practice has been used at Utah State University to provide a reliable source of genetically uniform plant materials for laboratory studies. No easily identifiable physical characteristics have been found yet to allow selection of easily rooted plants in the field. At present it is necessary to test the rooting ability of stems of individual plants on the propagation bench and to save the best rooting plants.

\section{Hormone Concentration and Interaction with Season of Collection}

In March, rooting percentages of spiny hopsage, shadscale, and four-wing saltbush cuttings were increased above those in the control treatments by all hormone concentrations applied (Fig. 2). Treatment with $0.3 \%$ IBA in talc powder appeared to be near optimum for adventitious root formation on shadscale. Concentrations above $0.3 \%$ reduced percent rooting of shadscale slightly, but no effects on root development, after initiation, were observed. Concentrations of IBA from $0.3 \%$ to

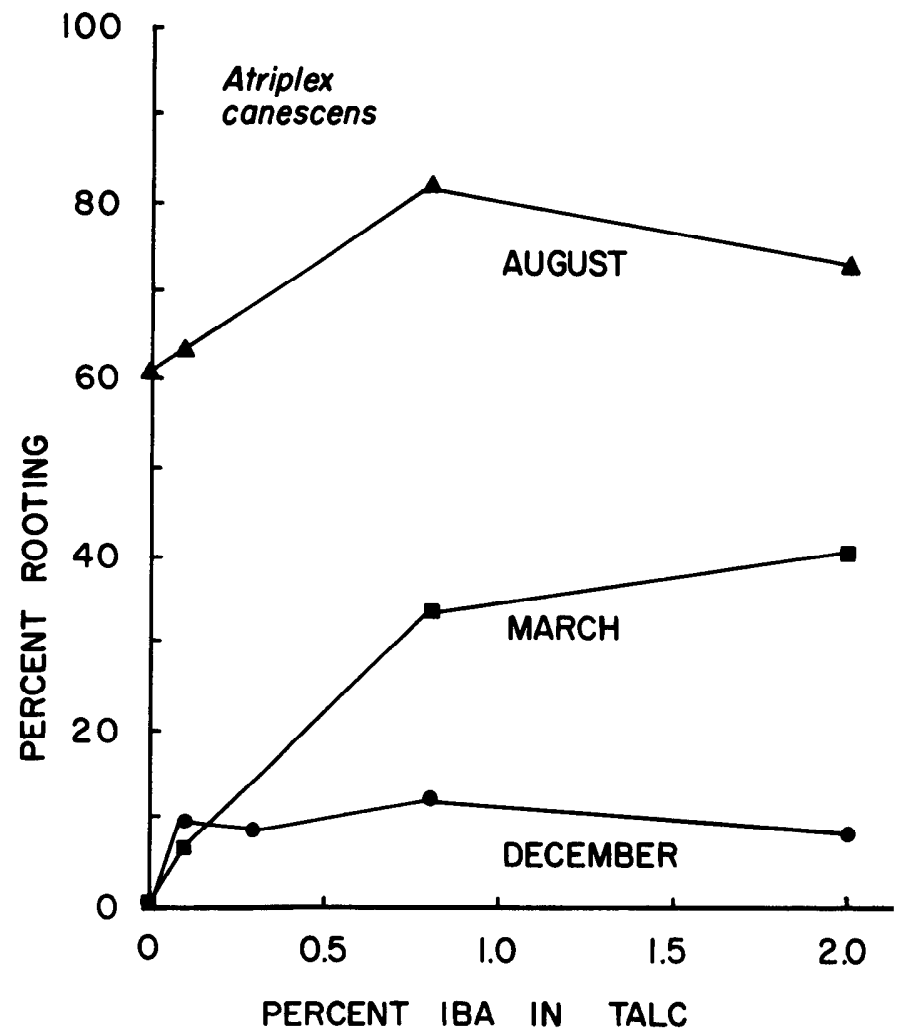

Fig. 3. Effect of date of collection on response of fourwing saltbush cuttings to various IBA concentrations. 
Table 2. Rooting percentage of greenhouse-grown fourwing saltbush as affected by length of cutting and portion of new leader used.

\begin{tabular}{|c|c|c|c|c|}
\hline \multirow{2}{*}{\multicolumn{2}{|c|}{$\begin{array}{l}\text { Time in } \\
\text { rooting chamber }\end{array}$}} & \multicolumn{3}{|c|}{ Length of stem cutting 1,3} \\
\hline & & $6 \mathrm{~cm}$ & $9 \mathrm{~cm}$ & $12 \mathrm{~cm}$ \\
\hline \multirow{4}{*}{2} & weeks & $23.8 \mathrm{a}$ & $47.6 \mathrm{~b}$ & $71.4 \mathrm{c}$ \\
\hline & & $42.9 \mathrm{ab}$ & $61.9 \mathrm{bc}$ & $100.0 \mathrm{~d}$ \\
\hline & & \multicolumn{3}{|c|}{ Portion of leader ${ }^{2,3}$} \\
\hline & & Top & Middle & Bottom \\
\hline 2 weeks & & $2.9 w$ & $22.9 x$ & $40.0 \mathrm{y}$ \\
\hline 4 weeks & & $22.9 x$ & $45.7 y$ & $60.0 \mathrm{z}$ \\
\hline
\end{tabular}

' Means of 3 replications of 7 cuttings. $0.3 \%$ IBA

"Means of 5 replications of 7 cuttings, $0.3 \%$ IBA

"Values within experiment followed by the same letter do not differ significantly at the (1) level.

$2.0 \%$ were equally effective in inducing rooting of spiny hopsage cuttings. A concentration of $2.0 \%$ IBA was only slightly more effective than a concentration of $0.8 \%$ IBA for promoting root initiation in fourwing saltbush.

The date of collection affected the rooting response of fourwing saltbush to hormone treatment (Fig. 3). Treatment of stem cuttings with IBA was required for any adventitious root initiation in December and March. The effectiveness of the hormone treatments was very limited in December but increased in March. In August, near the optimum time for collecting cuttings of fourwing saltbush, rooting exceeded $60 \%$ without hormone treatment, but treatment with $0.8 \%$ IBA still increased rooting an additional 20\%. Date of collection of fourwing saltbush cuttings appears to be more important to rooting success than whether or not the cuttings are treated with IBA, because even with hormone treatments, rooting percentages in December and March were less than for untreated cuttings in August.

\section{Effects of Length of Cutting and Stem Portion Used}

Longer cuttings of fourwing saltbush rooted better than shorter cuttings (Table 2). In an effort to produce the maximum number of rooted cuttings from a given amount of stem material it may be tempting to make the cuttings short. However, this practice may not achieve the desired result. Based on the 4-week data (Table 2) and using the same amount of total stem material, fifty $12 \mathrm{~cm}$ long cuttings would yield 50 rooted cuttings, while one hundred $6 \mathrm{~cm}$ long cuttings would yield 43 rooted cuttings. The larger cuttings also produced more vigorous plants. The growth habit of the plant and environmental conditions under which the plants were grown will determine the size of cuttings (length of leaders) that can be obtained, but for best results cuttings should probably be at least $8 \mathrm{~cm}$ long.
The woodier bottom portions of new fourwing saltbush leaders rooted better than the more herbaceous tips (Table 5). These results differ from those of Nord and Goodin (1970); however, their use of intermittent mist may have been more favorable for rooting of herbaceous material. Basal portions of leaders must be used for shadscale and some other spinescent shrubs since no secondary shoot growth will occur from the tip portions which loose their leaves and become spines.

\section{Greenhouse-Grown Vs. Field-Collected Cuttings}

Greasewood cuttings collected on March 24, 1976, and January 7, 1977, from greenhouse-grown plants rooted $40 \%$ and $32 \%$, respectively, while field-collected cuttings on those dates rooted only $0 \%$ and $7 \%$, respectively. Clearly, the environmental conditions experienced by the donor plants affect rooting of cuttings. Vegetative propagation of plants, such as greasewood, that have generally proved difficult to propagate by stem cuttings may be improved when these plants are grown in a nursery situation. Yearly variations in precipitation and temperature may also produce variations in the ability of stem cuttings to root.

Differences in environment may at least partially explain the significantly (.05 level) lower percent rooting of fourwing saltbush stem cuttings collected March 18, 1977, from Wildcat Mesa in southeastern Utah than of cuttings collected March 20, 1977. from Bonanza in northeastern Utah (Table 1). The winter of 1976-77 was generally dry, but the drought was much more severe on Wildcat Mesa than at Bonanza. However, genetic differences between populations may also be a contributing factor. Both fourwing saltbush populations were in approximately the same phenological stage (i.e. just beginning spring growth) at the time cuttings were collected.

\section{Literature Cited}

Alvarez-Cordero, E. 1978. Stem cutting propagation of big sagebrush (Artemisia tridentata Nutt.) MS Thesis, Utah State University, Logan, Utah. $122 \mathrm{p}$.

Ellern, S.J. 1972. Rooting cuttings of saltbrush (Atriplex halimus L.). J. Range Manage. 25: 154-155.

Freeman, D.C., L.G. Klikoff, and K.T. Harper. 1976. Differential resource utilization by the sexes of dioecious plants. Science 193: 597-599.

Hartman, H.T., and D.E. Kester. 1975. Plant Propagation Principles and Practices., Prentice-Hall, Inc., Englewood Cliffs, New Jersey. 662 p.

Nord, E.C., and J.R. Goodin. 1970. Rooting cuttings of shrub species for planting of California wildlands. U.S.D.A. For. Serv. Res. Note PSW-213. Pacific Southwest Forest and Range Experiment Station, Berkeley, CA. 4 pp.

Wieland, P.A.T., E.F. Frolich, and A. Wallace. 1971. Vegetative propagation of woody shrub species from the northern Mojave and southern Great Basin Desert. Madrono 21: 149-152.

Wiesner, L.D., and W.J. Johnson. 1977. Fourwing saltbrush (Atriplex (anescens) propagation techniques. J. Range Manage. 30: 154-156. 